\title{
ANALISIS KUALITAS AIR YANG DI KONSUMSI WARGA DESA BATU MERAH KOTA AMBON
}

\author{
${ }^{1}$ Janaba Renngiwur, ${ }^{2}$ Irvan Lasaiba dan ${ }^{3}$ Abajaidun Mahulauw \\ ${ }^{1,2,3}$ Staf Pengajar Jurusan Pendidikan Biologi FITK IAIN Ambon \\ E-mail: nabaerlet@gmail.com
}

\begin{abstract}
Abstrak: Hasil penelitian menunjukkan bahwa analisis kualitas air pada parameter fisika dan kimia pada semua sampel air memenuhi standar baku yang ditetapkan pemerintah sedangkan pada parameter bakteriologi hanya sampel air bor III yang kualitasnya baik dan layak untuk dikonsumsi sebagai air minum dan sampel air bor II memenuhi standar baku air bersih, adapun semua sampel lainnya telah tercemar bakteri. Berdasarkan hasil uji Kruskal Wallis diperoleh bahwa nilai uji $\chi 2_{\text {hitung }}>\chi^{2}$ tabel atau 9,651 $>5.991$ dengan sig: $0.008<0.05$. Maka tolak $\mathrm{H}_{0}$ dan terima $\mathrm{H}_{1}$, atau ada perbedaan yang signifikan antara kualitas air yang dikonsumsi warga Stain Desa Batu Merah Kota Ambon berdasarkan sarana air bersih yang digunakan atau salah satu sampel berbeda.
\end{abstract}

Kata Kunci: kualitas, air sumur, air bor dan air pdam

\section{AN ANALYSIS OF A QUALITY OF WATER THAT CONSUMED VILLAGERS BATU MERAH AMBON CITY}

Abstract: The research results show that the quality of water at analysis parameter physics and chemistry on all water sample raw up to the standards set by the government while on the parameter bacteriology is only sample water quality drill III good and suitable for consumption as fresh water and water sample drill II clean water up to the standards, as for other sample all else bacteria. Wallis obtained kruskal testing shows that the total amount of $\chi 2$ test $>\chi 2$ table or $9,651>5.991$ with a sig: $0.008<0.05$. Then turning $\mathrm{H}_{0}$ and receive $\mathrm{H}_{1}$, or there is no statistical difference between the quality of the water consumed by a red stone village residents stain ambon city based on clean water facilities used or one of different sample

\section{Keywords: The Quality Of, The Water Of A Well, Water Drill And Pdam}

Terbatasnya ketersediaan air baku menjadi salah satu masalah yang dihadapi dalam penyediaan layanan air bersih di Indonesia, belum meratanya pelayanan penyediaan air bersih terutama di daerah pedesaan, dan sumber air bersih yang ada belum dimanfaatkan 
secara maksimal. Bahkan di beberapa wilayah, sumber air bersih yang dimanfaatkan oleh PDAM telah tercemari oleh limbah industri dan limbah domestik, sehingga beban dalam pengolahan air bersih menjadi meningkat. Air bersih adalah air yang dipergunakan untuk keperluan sehari-hari dan kualitasnya memenuhi persyaratan kesehatan air bersih sesuai dengan peraturan perundang-undangan yang berlaku. Kualitas air yang baik meliputi uji kualitas secara fisika, kimia dan biologi, sehingga apabila dikonsumsi tidak menimbulkan efek samping untuk kesehatan. Untuk wilayah kota ambon dan sekitarnya air dapat diperoleh warga melalui beberapa cara diantaranya jalur PDAM, Sumur Bor, dan Sumur Timba yang dimiliki masyarakat.

Berdasarkan hasil wawancara yang disampaikan oleh kepala Perusahaan Daerah Air Minum (PDAM) Ambon Apong tetelepta kepada wartawan dari harian tribun timur bahwa "pelanggan PDAM di kota ambon kurang lebih 70 ribu jiwa, dan pihaknya mengalami krisis air bersih sebanyak $60 \%$ dari sumber air untuk melayani masyarakat. Sumber air yang dikelola PT DSA Air Besar desa Batu Merah kecamatan sirimau tidak bisa diharapkan karena kawasan tersebut telah mengalami krisis air bersih sejak awal januari 2016 dengan debit air tersisa $2.500 \mathrm{kubik} / \mathrm{hari"}$ (Anonim, 2006).

Air sebagai salah satu unsur penting di dalam proses metabolisme tubuh manusia dan sumber kehidupan bagi seluruh makhluk hidup merupakan anugerah dari Tuhan yang harus kita jaga, pelihara dan lestarikan guna kelangsungan hidup dimasa depan. Manusia akan lebih cepat meninggal karena kekurangan air dari pada kekurangan makanan. Di dalam tubuh manusia itu sendiri sebagian besar terdiri dari air. Tubuh orang dewasa, sekitar 55 - 60\% berat badan terdiri dari air, untuk anak-anak sekitar 65\%, dan untuk bayi sekitar $80 \%$.

\section{METODE PENELITIAN}

Metode penelitian yang digunakan yakni metode eksperimen berupa pengambilan sampel air di Stain Desa Batu Merah yang selanjutnya dilakukan uji sampel air di laboratorium Kesehatan Provinsi Maluku guna mengetahui kualitas sampel air yang dikonsumsi warga. Waktu Penelitian sejak tanggal 20 Juli - 21 September 2016. Pengambilan sampel dilakukan pada tanggal 20 - 21 juli 2016, selanjutnya dianalisis sejak tanggal 22 - 27 Juli 2016. Pengambilan sampel masing-masing kelompok sebanyak 3 lokasi sehingga terdapat 9 sampel air. Pengujian dilakukan sebanyak 3 kali pengulangan sehinga total pengujian sebanyak 9 × $3=27$ kali pengujian sampel. Variabel penelitian terdiri dari variabel bebas berupa sarana air minum yang digunakan warga Stain Desa Batu Merah Kota Ambon terdiri dari air sumur, air sumur bor dan air PDAM. Sedangkan variabel terikat berupa kualitas air yang meliputi parameter sifat fisika, kimia dan bakteriologis. Alat yang digunakan dalam penelitian ini disajikan pada tabel berikut ini. 
Tabel 1. Jenis Parameter, Alat dan Metode Pengujian Sampel

\begin{tabular}{|c|l|c|c|}
\hline No & \multicolumn{1}{|c|}{ Parameter } & Alat & Metode \\
\hline 1 & Bau & Indra Pembau & Organoleptik \\
\hline 2 & Rasa & Indra Perasa & Organoleptik \\
\hline 3 & Warna & Indra Penglihatan & $\begin{array}{c}\text { Perbandingan Warna dengan } \\
\text { Visual }\end{array}$ \\
\hline 4 & Suhu & Termometer & Termometrik \\
\hline 5 & Kekeruhan & Turbidimeter (Nefelometer) & Nephelometric \\
\hline 6 & $\begin{array}{l}\text { Jumlah Zat Padat } \\
\text { Terlarut }\end{array}$ & Timbangan Analitik & Elektrometri \\
\hline 7 & Ph & pH mater & Spektrofotometrik \\
\hline 8 & Kesadahan & Spektrofotometer & IKM/5.4.8/BLK-Promal \\
\hline 9 & E.Coli & Tabel MPN & TKM/5.4.8/BLK-Promal \\
\hline 10 & Total Coliform & Tabel MPN & IKM \\
\hline
\end{tabular}

Selain alat yang disebutkan diatas terdapat beberapa alat yang digunakan antara lain, gelas ukur, timbangan analitik, labu erlenmeyer, buret, pengaduk gelas, botol sampel air ukuran 1,5 ml sebanyak 9 buah, alat tulis, meteran, kamera digital, Sedangkan bahan berupa sampel air sumur, sampel air bor, sampel air PDAM, kertas tissu, dan tali rafia. Data yang terkumpul terlebih dahulu di edit, dikoding selanjutnya dilakukan analisis data menggunakan program SPSS for windows fersi 16.

\section{HASIL DAN PEMBAHASAN}

Kota Ambon terletak di pulau Ambon merupakan ibukota Provinsi Maluku. Secara astronomis wilayah administrasi kota ambon terletak antara $3^{0}-4^{0}$ Lintang Selatan dan $128^{0}-129^{0}$ Bujur Timur. Memiliki luas wilayah $377 \mathrm{~km}^{2}$ dimana luas daratan mencapai $359.45 \mathrm{~km}^{2}$ dan laut seluas $17.55 \mathrm{~km}^{2}$, dengan panjang garis pantai $98 \mathrm{~km}$. Desa batu merah merupakan salah satu desa di kecamatan sirimau dengan jumlah penduduk terbesar dan menduduki peringkat pertama di provinsi Maluku, jumlah jiwa di desa Batu Merah sebanyak 97700 jiwa yang menempati 21 Rukun Warga dan 97 Rukun Tetangga. Tempat pengambilan sampel air berada di RW 017 Kompleks Stain Ambon desa Batu Merah. Di mana denah lokasi pengambilan sampel dalam penelitian ini ditunjukkan pada gambar berikut ini. 


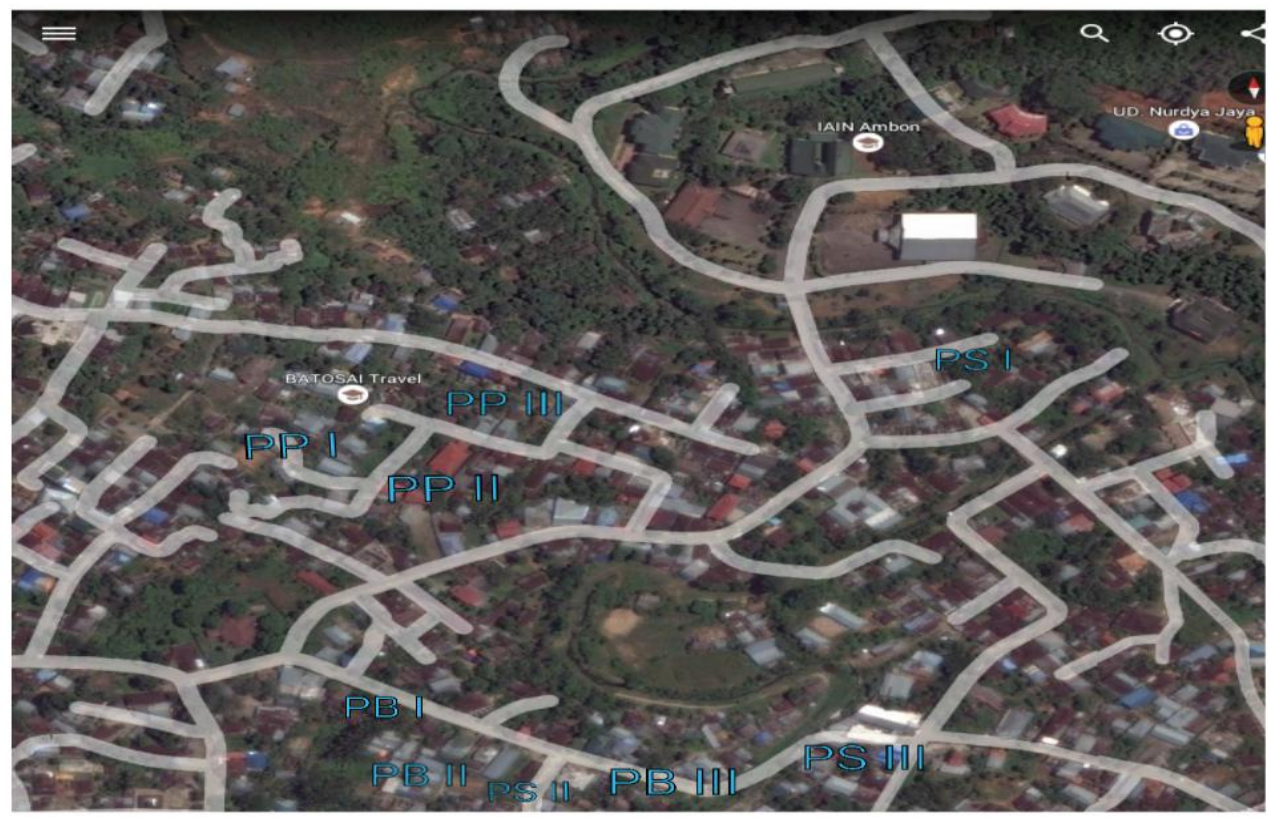

Gambar 1. Denah Lokasi Pengambilan Sampel Air

Kualitas air dalam penelitian ini mengacu kepada standar baku yang ditetapkan pemerintah melalui peraturan pemerintah nomor 82 tahun 2001 tentang pengelolaan kualitas air dan pengendalian pencemaran air serta standar baku air minum dalam peraturan menteri kesehatan nomor 492/Menkes/per/IV/2010 tentang persyaratan kualitas air Minum. Air minum adalah air yang melalui proses pengolahan atau tanpa proses pengolahan yang memenuhi syarat kesehatan dan dapat langsung diminum. Air minum aman bagi kesehatan apabila memenuhi persyaratan fisika, mikrobiologis, kimiawi dan radioaktif yang dimuat dalam parameter wajib dan parameter tambahan (Permenkes No. 49, 2010). Air yang berkualitas baik harus memenuhi persyaratan secara fisika, kimia dan bakteriologis (PP No 82, 2001).

Air yang berkualitas baik harus memenuhi persyaratan fisika yakni airnya tawar atau tidak berasa, tidak berbau, tidak berwarna, jernih atau tidak keruh, suhunya normal serta tidak mengandung padatan. Hasil pengujian Parameter fisika berupa bau dan rasa air menunjukkan bahwa $100 \%$ sampel air yang diuji memenuhi standar baku ditetapkan pemerintah. Hasil yang tampak pada gambar 2 menunjukkan bahwa dari 9 sampel air yang diuji pada kedua parameter yakni bau dan rasa air, dengan melakukan perlakuan sebanyak tiga kali pengulangan untuk tiap sampel, hasilnya adalah semua sampel layak untuk digunakan sebagai air minum karena tidak berbau serta berasa tawar. Hal ini menunjukkan bahwa air tersebut bersih serta tidak terkontaminasi oleh zat yang dapat membahayakan kesehatan. Srikandi Fardiaz mengemukakan bahwa bau pada air tergantung dari sumber airnya (Srikandi Fardiaz, 1992). Hasil ini ditunjukkan pada gambar 2 berikut ini 


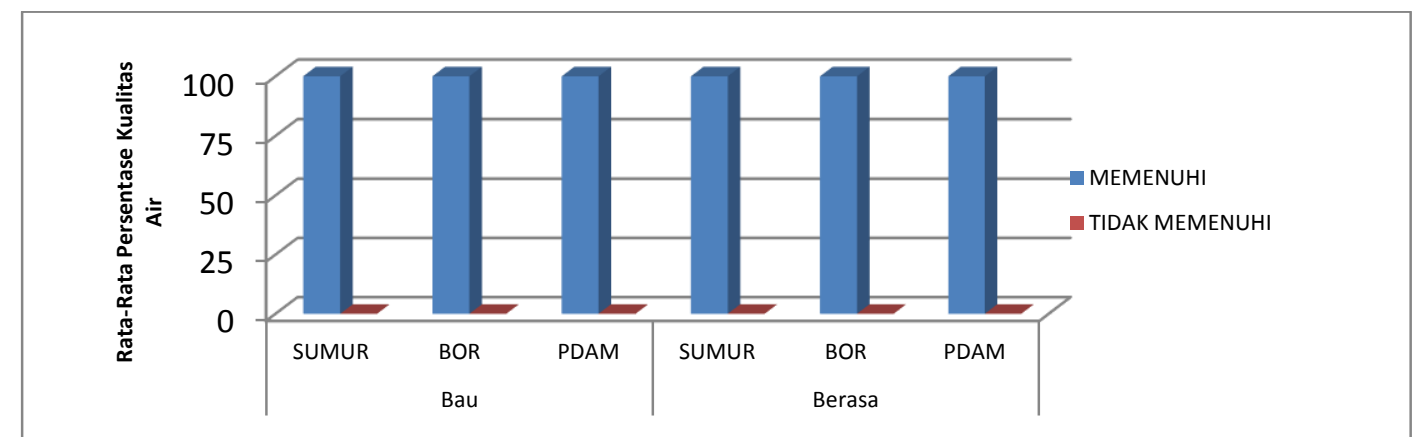

Gambar 2. Grafik Hasil Analisis Bau dan Rasa Air

Bau pada air dapat disebabkan karena adanya bahan-bahan organik yang membusuk, persenyawaan kimia, adanya algae serta tumbuhan dan hewan air lainnya. Air yang mempunyai bau tidak normal juga dianggap memiliki rasa yang tidak normal (Moersidik, 1999). Selain parameter fisika tentang bau dan rasa air, hasil pengujian laboratorium tentang warna pada sampel air sumur, air bor dan air PDAM, datanya menunjukkan bahwa 9 sampel air yang diuji hasil pengukuran rata-rata sampel yakni 5 TCU, nilai ini lebih rendah dari standar baku yang ditetapkan yakni 15 TCU sehingga air tergolong tidak berwarna. Dengan demikian untuk parameter warna pada semua sampel air layak untuk dikonsumsi oleh warga. Hasil ini seperti ditunjukkan pada gambar 3 berikut ini.

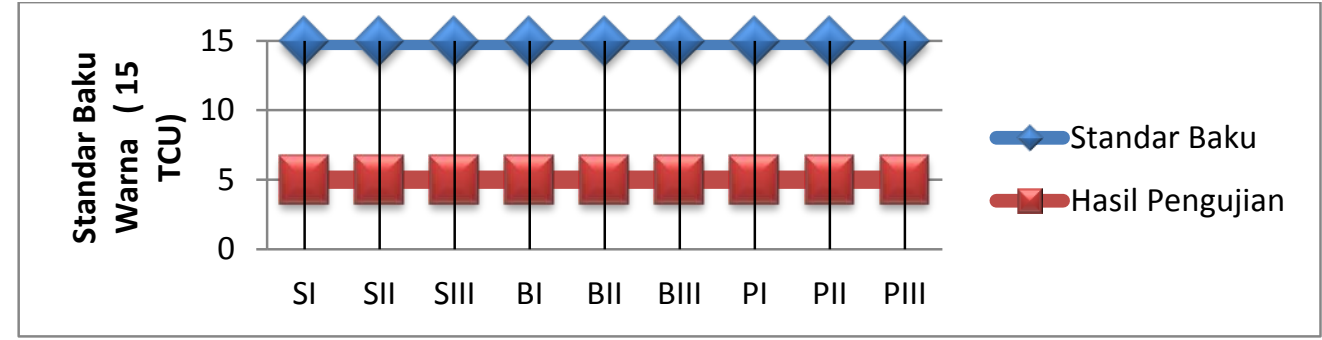

Gambar 3. Grafik Standar baku Warna dengan Hasil Uji Sampel Air

Warna pada air dapat disebabakan oleh kontak antara air dengan bahan organik seperti daun dan kayu yang membusuk hingga tingkatan tertentu. Tanin, asam humus dan bahan berasal dari humus dianggapsebagai bahan yang memberi warna utama. Kadang besi ada sebagai bahan yang berasal dari humus dan menghasilkan warna dengan potensi tinggi. Air yang mengandung bahan-bahan pewarna alami yang berasal dari rawa dan hutan, tidak mempunyai sifat-sifat yang membahayakan atau toksis. Namun demikian bahan-bahan tersebut memberikan warna kuning kecoklatan pada air sehingga tidak bagus dipandang secara estetika sehingga tidak disukai oleh masyarakat.

Beberapa parameter fisika lainnya diantaranya suhu, kekeruhan dan jumlah zat terlarut, hasilnya menunjukkan nilai yang berada dibawah standar baku yang ditetapkan sehingga layak untuk dikonsumsi warga. Gambar 4 berikut menunjukkan data suhu air dari 9 sampel yang diuji. Suhu air sebaiknya tidak terlalu panas dan sejuk, air yang baik harus memiliki suhu yang sama dengan suhu udara yakni sekitar $28^{\circ} \mathrm{C}$, sehingga tidak 
terjadi pelarutan zat kimia yang ada pada saluran atau pipa yang dapat membahayakan kesehatan, menghambat reaksi-reaksi biokimia didalam saluran atau pipa, dan mikroorganisme patogen tidak mudah berkembang.

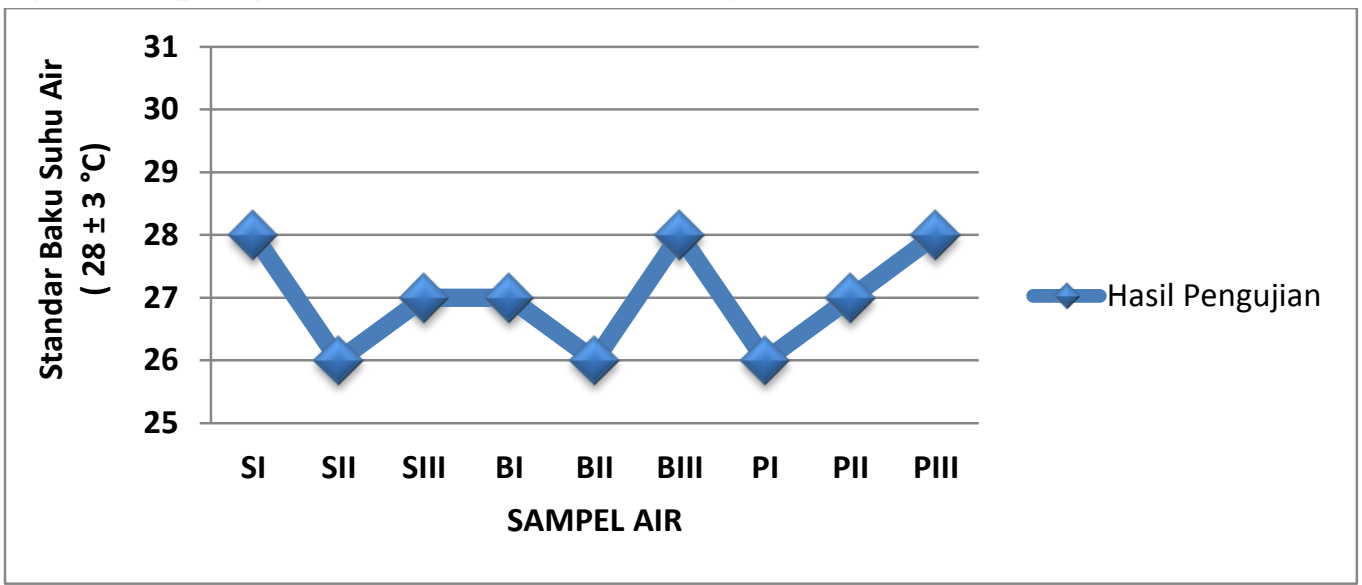

Gambar 4. Grafik Hubungan Standar Baku dengan Hasil Pengukuran Suhu Air

Hasil pengujian menunjukkan bahwa rata-rata 9 sampel yang terdiri dari air sumur 3 sampel, air bor 3 sampel dan air PDAM juga 3 sampel semuanya berada pada kisaran suhu $26{ }^{\circ} \mathrm{C}$ hingga $28{ }^{\circ} \mathrm{C}$. Hasil ini masih berada pada interval standar baku yang ditetapkan pemerintah untuk suhu air minum yang dikonsumsi warga yakni sebesar suhu udara $\pm 3{ }^{\circ} \mathrm{C}$. Dengan demikian air tersebut layak untuk dikonsumsi warga. Air yang memiliki suhu diatas atau dibawah suhu udara berarti mengandung zat-zat terlarut tertentu atau sedang terjadi proses penguraian bahan organik oleh mikroorganisme yang menghasilkan energi yang mengelurkan atau menyerap energi dalam air. Hasil pengujian tentang kekeruhan air menunjukkan bahwa 9 sampel yang diuji nilainya berada pada angka 0.00 NTU hingga 0.02 NTU hasil ini jauh lebih kecil dari standar baku yang ditetapkan pemerintah yakni sebesar 5 NTU, dengan demikian air tersebut sangat layak untuk dikonsumsi warga. Hasil ini tampak pada gambar 5 berikut ini.

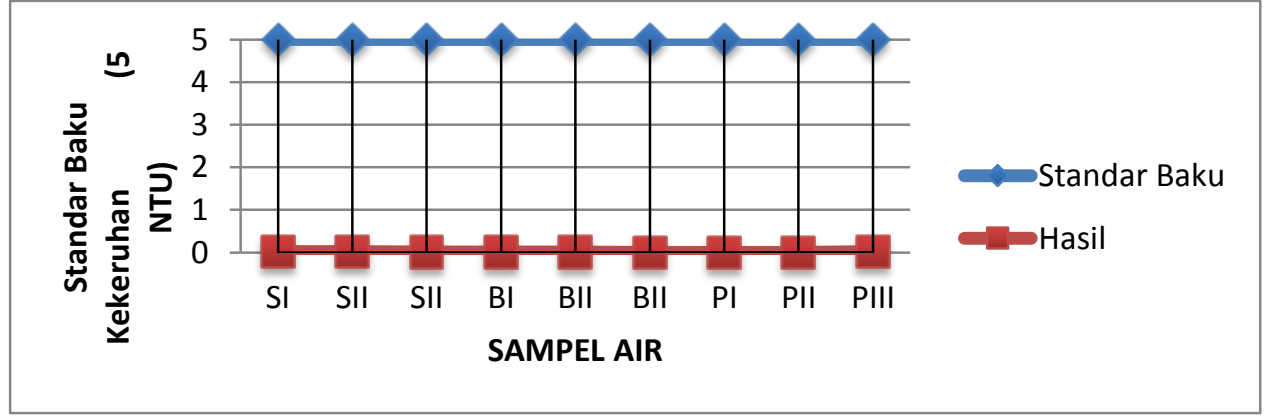

Gambar 5. Grafik Hubungan Standar Baku dengan Pengukuran Kekeruhan Air

Standar baku parameter fisika untuk jumlah zat padat terlarut sebesar $500 \mathrm{mg} / \mathrm{l}$. Sedangkan hasil pengujian pada 9 sampel air menunjukkan bahwa rata-rata hasil 
pengujian berada dibawah standar baku yang ditetapkan. Hasil ini ditunjukkan pada gambar 6 berikut.

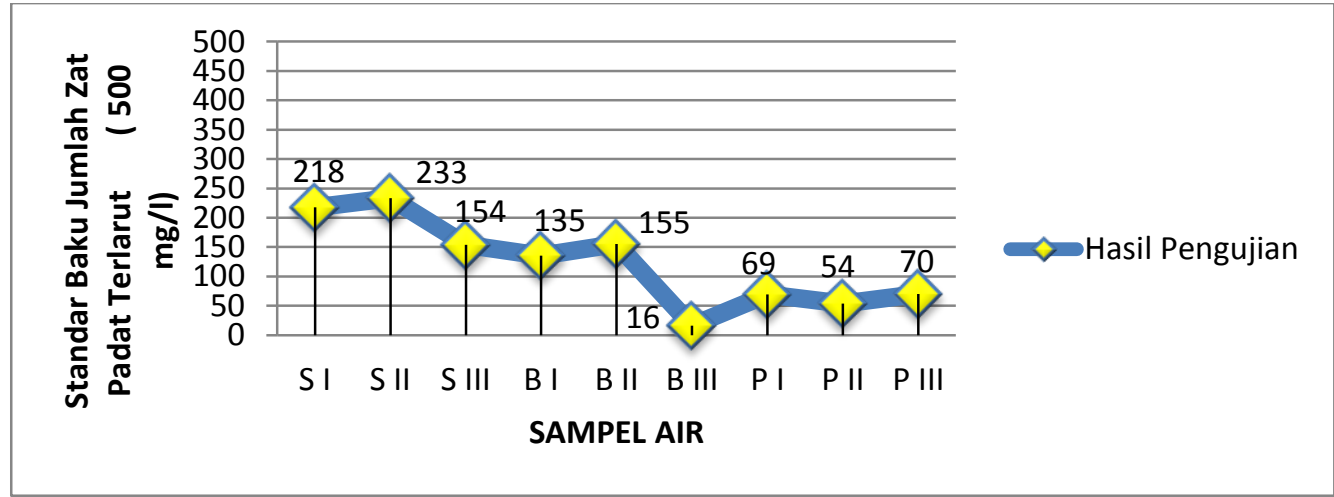

Gambar 6. Grafik Hubungan Standar Baku dengan Hasil Pengukuran TDS Air

Menurut Tyas Djuhariningrum klasifikasi air tanah menurut kandungan jumlah zat padat terlarut dikelompokkan atas beberapa bagian yakni air lunak pada kisaran $<100$ $\mathrm{mg} / \mathrm{l}$, air bersih 100 - $500 \mathrm{mg} / \mathrm{l}$, air sadah karbonat $500-1.000 \mathrm{mg} / \mathrm{l}$, air sadah non karbonat $1.000-2.000 \mathrm{mg} / \mathrm{l}$, air payau $2.000-10.000 \mathrm{mg} / \mathrm{l}$, air asin $10.000-100.000$ $\mathrm{mg} / \mathrm{l}$, air garam > $100.000 \mathrm{mg} / \mathrm{l}$ (Tyas Djuharinungrum, 2005). Berdasarkan data tersebut maka dapat dijelaskan hasil rata-rata yang ditunjukkan pada grafik 6 bahwa ketiga sampel air PDAM dan Sampel Air bor III termasuk kategori air lunak sedangkan sampel air bor I dan II serta semua ketiga sampel air sumur termasuk dalam kategori air bersih. dengan demikian semua sampel air tersebut layak untuk dikonsumsi oleh warga karena memenuhi standar baku yang telah ditetapkan oleh pemerintah.

Selain uji kualitas untuk parameter fisika, juga dilakukan pengujian terhadap parameter kimia yakni $\mathrm{pH}$ dan Kesadahan air. Hasil pengujian $\mathrm{pH}$ air ditunjukkan pada gambar 7 berikut ini.

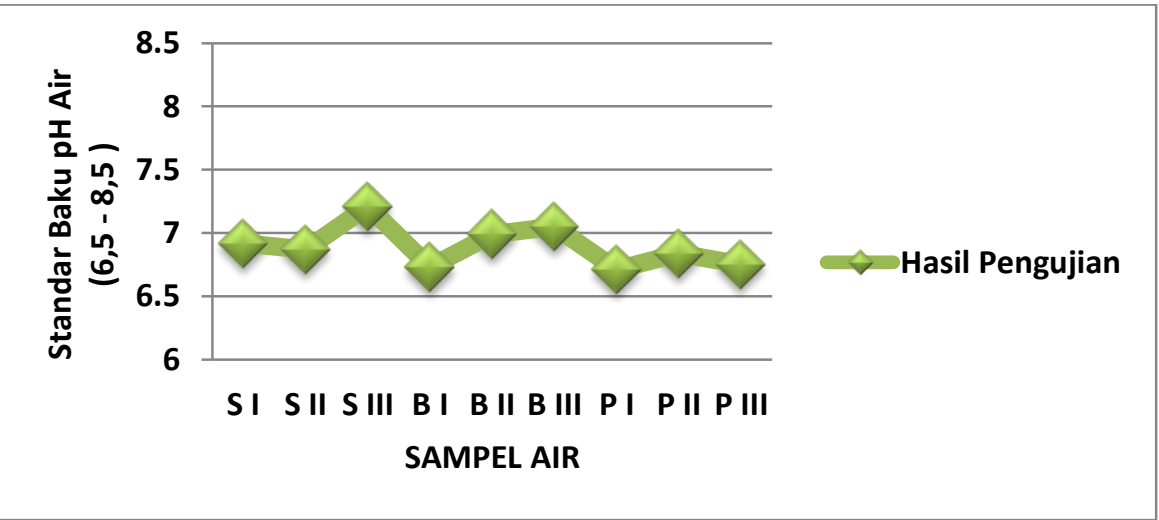

Gambar 7. Grafik Hubungan Standar Baku pH dengan Hasil Uji Air

Tampak pada gambar 7 bahwa nilai rata-rata $\mathrm{pH}$ untuk semua sampel pada ketiga kelompok air memenuhi standar baku yang ditetapkan pemerintah, yakni berada pada nilai interval 6,5-8,5. dengan rata-rata $\mathrm{pH}$ pada kategori netral atau sama dengan 7 . Air 
adalah bahan pelarut yang baik sekali, maka sebaiknya $\mathrm{pH}$ air adalah netral, tidak asam dan juga basa, sehingga mencegah terjadinya pelarutan logam berat, dan korosi jaringan distribusi air, sehingga dapat merusak kualitas air.

Gambar 8. berikut merupakan hubungan standar baku air dengan hasil pengujian kesadahan pada 9 sampel air. Kadar maksimum yang diperbolehkan yakni sebesar 500 $\mathrm{mg} / \mathrm{l}$ sedangkan hasil pengujian kesadahan air pada 9 sampel berada pada kisaran antara 9,88 mg/l sampai 160,8 mg/l. nilai tersebut menunjukkan bahwa tingkat kesadahan air pada semua sampel yang diuji hasilnya berada jauh dibawah standar baku yang ditetapkan pemerintah, sehingga semua sampel air tersebut layak untuk dikonsumsi oleh masyarakat.

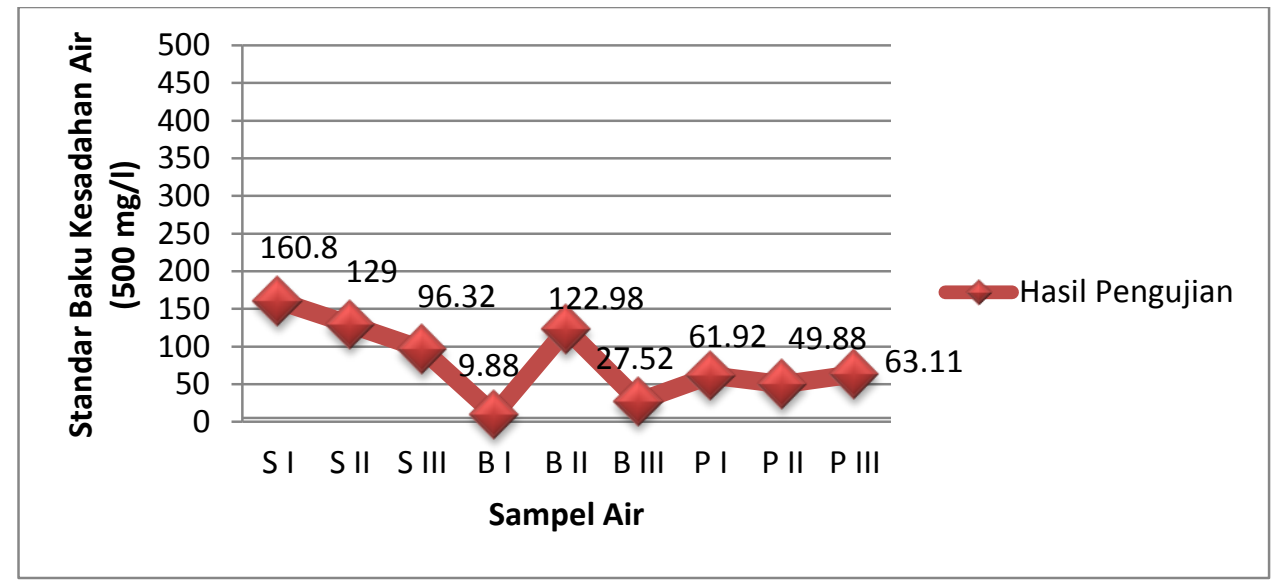

Gambar 8. Grafik Hubungan Standar Baku Kesadahan dengan Hasil Uji air

Hasil analisis kandungan bakteri berupa Escherichia Coli dan Total Coliform pada sampel air sumur, air bor dan air PDAM di sekitar Stain Ambon Khususnya RW 18 berkisar antara 0 hingga 1898 MPN/100 ml seperti ditinjukkan pada gambar 9. Nilai yang tampak pada gambar menunjukkan bahwa sampel air yang dianalisis terdapat kandungan Escherichia Coli dan Total Coliform yang sangat tinggi.

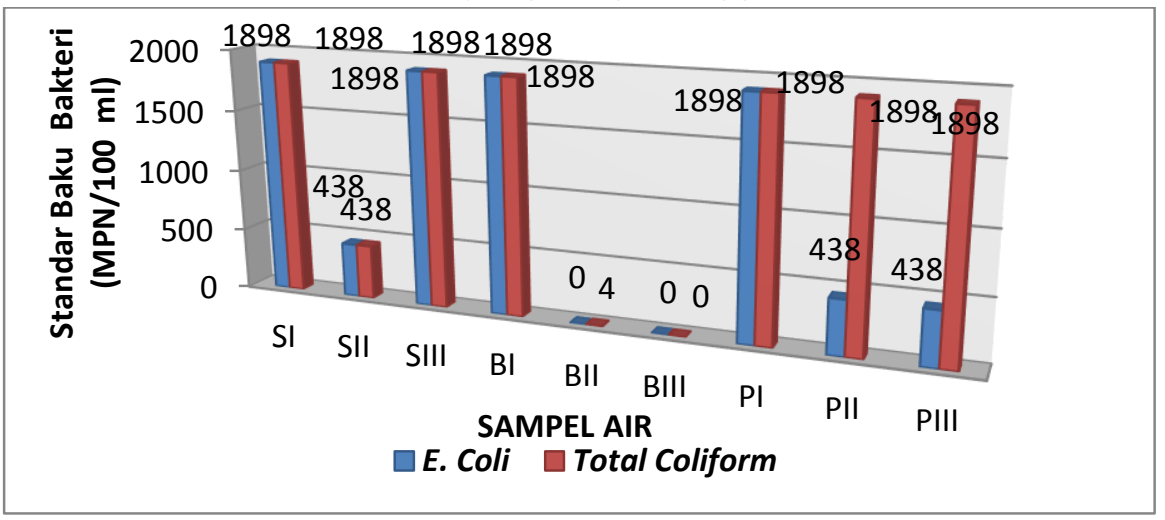

Gambar 9. Grafik Hubungan Standar Baku Bakteri dengan Hasil Uji Air

Berdasarkan data yang ditunjukkan pada gambar 9 dapat dinyatakan bahwa jika ditinjau dari standar baku air minum yang ditetapkan pemerintah pada parameter bakteriologi maka sampel air yang kualitasnya baik hanya 1 sampel yakni sumur bor 3 , 
karena kandungan bakteri E. coli maupun Total coliform tidak ditemukan pada sampel tersebut, atau kandungan $E$. coli maupun Total coliform jumlahnya $=0 \mathrm{mg} / \mathrm{L}$, sebaliknya 8 sampel lainnya telah tercemari bakteri baik E. coli maupun Total coliform. Namun jika mengacu pada Peraturan pemerintah tentang standar baku air bersih maka pada parameter bakteriologi maka sampel air yang kualitasnya baik hanya 2 sampel yakni sumur bor 2 dan 3, karena kandungan bakteri E. coli maupun Total coliform yang ditemukan pada sampel tersebut jumlahnya $<100 \mathrm{mg} / \mathrm{L}$, sebaliknya 7 sampel lainnya telah tercemari bakteri baik E. coli maupun Total coliform.

Berdasarkan hasil observasi yang diperoleh dilapangan menunjukkan bahwa adanya kontaminasi bakteri pada sampel air dapat disebabkan oleh beberapa faktor yakni dekatnya jarak septic tank dengan sumber air disebabkan karena luas lahan yang dimiliki warga yang sangat terbatas, serta jumlah penduduk yang padat, sehingga mengakibatkan jarak septic tank dengan sumber air bersih menjadi berdekatan. Keadaan ini diperperah lagi dengan tekstur tanah yang memiliki daya serap air yang tinggi terutama pada musim hujan, sehingga pencemaran terhadap sumber air menjadi semakin besar.

Hasil ini sejalan dengan pendapat yang disampaikan oleh Lintje Boekoesoe bahwa faktor yang dapat mempengaruhi jumlah bakteri E. coli pada sumber air bersih adalah jarak jamban dengan sumber air bersih (Lintje Boekoesoe, 2010). Jarak septic tank dengan sumber air bersih yang disampaikan oleh R. Prajawati (2008). Serta kondisi fisik sumber air bersih yang dikemukakan oleh H. Kusnoputranto. Juga pendapat yang disampaikan oleh Arif Sumantri bahwa keberadaan bakteri pada sumber air juga dapat disebabkan oleh kedalaman permukaan air tanah yang kedap air (Arif Sumantri, 2010).

Secara keseluruhan hasil analisis kualitas air menunjukkan bahwa pada parameter fisika dan kimia semua sampel air sangat memenuhi standar baku mutu yang ditetapkan pemerintah, karena hasil yang diperoleh masih pada rentang nilai yang diperbolehkan sedangkan pada parameter bakteriologi hanya sampel air bor III yang kualitasnya baik dan layak untuk dikonsumsi sebagai air minum dan sampel air bor II memenuhi standar baku air bersih, adapun semua sampel lainnya telah tercemar bakteri.

Berdasarkan hasil uji statistik nonparametrik berupa uji Kruskal Wallis diperoleh bahwa nilai uji $\chi 2$ hitung $=2$.894. Sebagai pembanding digunakan $\chi 2$ tabel $=$ untuk $\mathrm{df}=\mathrm{k}$ $-1=3-1=2$ maka diperoleh $\chi 2$ tabel $=5.991$, karena $\chi 2$ hitung $<\chi 2$ tabel atau $2.894<$ 5.991 dengan sig: $0.235>0.05$. Dengan demikian berdasarkan hasil analisis diputuskan tolak $\mathrm{H}_{1}$ dan terima $\mathrm{H}_{0}$, atau tidak ada perbedaan yang nyata antara kualitas air bersih yang dikonsumsi warga Stain Desa Batu Merah Kota Ambon berdasarkan sarana air bersih yang digunakan atau $\mu 1=\mu 2=\mu 3$. Atau dapat dikatakan bahwa hasil analisis Uji statistik menunjukkan bahwa rata-rata kualitas air yang dikonsumsi warga STAIN berdasarkan sarana air yang diperoleh yakni air sumur, air bor maupun air PDAM, memiliki kualitas yang sama atau tidak berbeda satu sama lain secara signifikan. 


\section{KESIMPULAN}

1. Secara keseluruhan hasil analisis kualitas air menunjukkan bahwa pada parameter fisika dan kimia semua sampel air sangat memenuhi standar baku mutu yang ditetapkan pemerintah, karena hasil yang diperoleh masih pada rentang nilai yang diperbolehkan sedangkan pada parameter bakteriologi hanya sampel air bor III yang kualitasnya baik dan layak untuk dikonsumsi sebagai air minum dan sampel air bor II memenuhi standar baku air bersih, adapun semua sampel lainnya telah tercemar bakteri.

2. Berdasarkan uji Kruskal Wallis diperoleh bahwa $\chi^{2 h i t u n g}<\chi 2$ tabel atau $2.894<$ 5.991 dengan sig: $0.235>0.05$, maka tolak $\mathrm{H}_{1}$ dan terima $\mathrm{H}_{0}$, atau tidak ada perbedaan yang nyata antara kualitas air yang dikonsumsi warga Stain Desa Batu Merah Kota Ambon berdasarkan sarana air bersih yang digunakan atau $\mu 1=\mu 2=\mu 3$. Atau dapat dikatakan bahwa hasil analisis Uji statistik menunjukkan bahwa rata-rata kualitas air yang dikonsumsi warga Stain berdasarkan sarana air yang diperoleh yakni air sumur, air bor maupun air PDAM, memiliki kualitas yang sama atau tidak berbeda satu sama lain secara signifikan.

\section{SARAN}

1. Bagi masyarakat secara umum dan khususnya kepada pemilik dan pengguna sarana air baik sumur, air bor maupun air PDAM agar secara berkala melakukan pengujian terhadap kualitas air yang dikonsumsi sehingga dapat mencegah efek yang nanti diakibatnya oleh air yang telah tercemar.

2. Kepada instansi terkait dalam hal ini dinas kesehatan maupun lembaga lain yang terkait agar rutin memberikan penyuluhan dan pemahaman kepada masyarakat tentang air yang bersih dan layak untuk dikonsumsi yang sesuai dengan standar baku mutu yang telah ditetapkan pemerintah.

3. Kepada peneliti lain agar dapat melanjutkan hasil penelitian ini guna melihat faktorfaktor yang menyebabkan bakteri dapat mencemari sarana air yang dikonsumsi warga serta cara yang efektif dan efisien yang dapat dilakukan guna menghilangkan kandungan bakteri pada sarana air minum agar dapat meningkatkan kualitas air yang dikonsumsi warga.

\section{DAFTAR PUSTAKA}

Anonim. 2016. Ambon Krisis Air Bersih. Harian Tribun Maluku. www.tribunmaluku.com diakses online tanggal 28 maret 2016

Anonim. 2016. Dasyatnya Pengaruh Air dalam Al Quran. https://www.islampos.com/dasyatnya-pengaruh-air-dalam-al-Quran-205184 di akses on line 30 maret 2016. 
Boekoesoe Lintje. 2010. Tingkat Kualitas Bakteriologis Air Bersih di desa Sosial Kecamatan Paguyaman kabupaten Baelemo. Jurnal Inovasi, Vol 7 No 4 Desember 2010. Hal. 240-251.

Djuhariningrum Tyas. 2005. Penentuan Total Padat Terlarut Dalam Memprediksi

Kualitas Air Tanah Dari Berbagai Contoh Air. Pusat Pengembangan Geologi

Batan. Bandung.

Fardiaz Srikandi. 1992. Mikrobiologi Pangan 1. PT Gramedia Pustaka Utama. Jakarta.

Kusnoputranto H. __. Kesehatan Lingkungan. Direktorat Jenderal Pendidikan Tinggi,

Departemen Pendidikan dan Kebudayaan. Jakarta.

Moersidik. 1999. Analisis Kualitas Air. Universitas Terbuka. Jakarta.

Peraturan Menteri Kesehatan Nomor 492/Menkes/per/IV/2010 Tentang Persyaratan

Kualitas Air Minum, Pdf, diakses online pada tanggal 5 mei 2016

Prajawati R. 2008. Hubungan Konstruksi dengan Kualitas Mikrobiologis Air Sumur Gali.

Ruwa Jurai, Vol 8

Soetrisno. 2004. Teknik Sumber Daya Air. Penerbit Erlangga. Jakarta.

Sumantri Arif. 2010. Kesehatan Lingkungan dalam Perspektif Islam. Prenada Media. Jakarta.

Sutrisno, dkk. 2006.Teknologi Penyediaan Air Bersih. PT Rineka Cipta. Jakarta.

Susana. 2003. Air Sebagai Sumber Kehidupan. Pusat Penelitian Oseanograsi-LIPI. Jakarta.

Wardhana W. A. 2004. Dampak Pencemaran Lingkungan. Andi. Yogyakarta. 